\title{
Relation between various chromium compounds and some other elements in fumes from manual metal arc stainless steel welding
}

\author{
Wanda Matczak, Jadwiga Chmielnicka
}

\begin{abstract}
For the years 1987-1990 160 individual samples of manual metal arc stainless steel (MMA/SS) welding fumes from the breathing zone of welders in four industrial plants were collected. Concentrations of soluble and insoluble chromium (Cr) III and $\mathrm{Cr}$ VI compounds as well as of some other welding fume elements (Fe, Mn, Ni, F) were determined. Concentration of welding fumes in the breathing zone ranged from 0.2 to $23.4 \mathrm{mg} / \mathrm{m}^{3}$. Total $\mathrm{Cr}$ amounted to $0.005-0.991 \mathrm{mg} / \mathrm{m}^{3}$ (including $0.005-0.842 \mathrm{mg} / \mathrm{m}^{3} \mathrm{Cr}$ VI). Total Cr content of fumes varied from $0 \cdot 1$ to $7 \cdot 4 \%$. The distribution of particular $\mathrm{Cr}$ compounds was: $52.6 \%$ soluble Cr (including $50 \cdot 7 \%$ Cr VI), $65.5 \%$ total Cr VI, and $11.4 \%$ insoluble Cr VI. The results obtained indicate that MMA/SS welding is a process that could be highly hazardous to human health. Evaluation of occupational exposure has shown that MMA/SS welders may exceed the admissible concentrations of soluble and insoluble $\mathrm{Cr}$ VI forms as well as of Mn and Ni. In the plants investigated the sum of the ratios of concentrations of particular welding fumes in the breathing zone of welders exceeded corresponding maximum allowable concentration values by 24 times (including 17 times for total Cr VI). Due to the variety and changeability of particular parameters occurring in the working environment, the composition of MMA/SS welding fumes (in the welder's breathing zone) is so variable that it is not possible to assess the exposure by means of
\end{abstract}

Nofer's Institute of Occupational Medicine, Department of Chemical Hazards, 90-950 Lodz, Teresy 8, Poland

W Matczak

Medical Academy, Institute of Environmental Research and Bioanalysis, Department of Toxicological Chemistry, 90-151, Lodz, Muszynskiego 1, Poland

J Chmielnicka one universal exposure indicator (maximum additive hygienic limit value). The evaluation should be based on the results of measurements of concentrations of particular elements in welding fumes.

\section{(British Journal of Industrial Medicine 1993;50:244-251)}

Occupational exposure to chromium $(\mathrm{Cr})$ poses a serious problem and many studies on the biological effects of chromates have been conducted. ${ }^{1-3}$ Chromates are well recognised as human carcinogens and suspected of genotoxic action. ${ }^{245}$

Numerous epidemiological studies have been carried out to determine the relation between human exposure to chromates and the occurrence of lung cancer, but only some of them include measurements of exposure in stainless steel (SS) welders. ${ }^{67}$ The level of exposure of workers to metal fumes, fluxes, and gases depends, to a large extent, on the type of welding. ${ }^{2}$ Welding techniques vary, although most stainless steel welding is performed with electric arc (manual metal arc (MMA)) processes.

The chemical composition of MMA/SS welding fumes and details of occupational exposure of welders in the workplace have been reviewed. ${ }^{28} \mathrm{Par}-$ ticular attention has been paid to $\mathrm{Cr}$ oxidation state in welding fumes. ${ }^{29}$

A few studies devoted to occupational exposure of MMA/SS welders have considered $\mathrm{Cr}$ compounds of different solubilities and at different oxidation states. $^{910}$ In our previous studies, the analytical procedure for simultaneous determination of soluble and insoluble Cr III and Cr VI as well as of some other elements in welding fumes was presented for evaluation of occupational exposure of welders. ${ }^{11-15}$

This study was aimed at evaluation of welders' occupational exposure to $\mathrm{Cr}$ III and $\mathrm{Cr}$ VI compounds, as well as to some other elements in MMA/ SS welding fumes, in selected Polish industries.

Materials and methods SUBJECTS AND EXPOSURE

The study covered the workers at a plant where some 
Table 1 Composition of welding materials

\begin{tabular}{|c|c|c|c|c|}
\hline \multirow[b]{2}{*}{ Plants } & \multirow[b]{2}{*}{ Stainless steel } & \multirow[b]{2}{*}{ Electrode type } & \multicolumn{2}{|l|}{ Content } \\
\hline & & & $\mathrm{Cr}(\%)$ & $\mathrm{Ni}(\%)$ \\
\hline A & $1 \mathrm{H} 18 \mathrm{~N} 9 \mathrm{~T}$ & $\begin{array}{l}\text { ES 18-8 SiBB } \\
\text { ES 18-8 2B }\end{array}$ & 18 & 8 \\
\hline B & $08 \mathrm{H} 18 \mathrm{~N} 10 \mathrm{~T}$ & $\begin{array}{l}\text { EA } 400 / 10 T \\
\text { EA 395/9 } \\
\text { AVESTA P-5 }\end{array}$ & $\begin{array}{l}17-19 \\
13 \cdot 5-17 \\
22\end{array}$ & $\begin{array}{r}9-12 \\
22-27 \\
12-14\end{array}$ \\
\hline C & OH $17 \mathrm{~T}$ & ES 20-1-6B & 18 & 8 \\
\hline D & H 18 N9T & $\begin{array}{l}\text { ES } 188 B \\
\text { MVRAC/DC (AR) }\end{array}$ & $\begin{array}{l}18 \\
19 \cdot 5\end{array}$ & $\begin{array}{r}8 \\
10\end{array}$ \\
\hline
\end{tabular}

items of equipment for power stations were manufactured (A), a chemical industry plant (B), and two metal industry plants $(C, D)$. All plants were equipped with dilution ventilation with blowing and exhaust systems. Local exhaust systems were used only at the welding sites in plant C. Table 1 presents the materials used in the welding process in particular plants.

\section{PROCEDURE}

Throughout 1988-90 about 120 individual samples of MMA/SS welding fumes in the breathing zone of welders and 40 individual samples from welder assistants in the four industrial plants (A, B, C, D) were collected. During the regular eight hour shift the welders were occupied either with welding or with assembly work connected with the welding process for about six and a half to seven hours. Two air samples a shift were collected simultaneously in a welder's breathing zone (behind the face guard), each over a period of about seven hours. Two stage personal air sampling was applied (Casella AFC-123, flow rate $1.91 / \mathrm{min}$ ). The respirable fraction of dust was collected on a membrane filter (Sartorius 11304, $0.8 \mu \mathrm{m}, \emptyset 37 \mathrm{~mm}$ ) and a glass fibre filter (Whatman $\mathrm{GF} / \mathrm{A}, \emptyset 37 \mathrm{~mm}$ ). Methods of sample collection, preparation, and analytical procedures have been presented earlier. ${ }^{112}$

Before and after sampling filters were dried at $105^{\circ} \mathrm{C}$ for one hour, then cooled in a desiccator and weighed. Next the mass of dry substance was calculated by comparing filter mass before and after the sampling.

\section{Membrane filter}

In one part of the sample from the membrane filter $\mathrm{Fe}, \mathrm{Mn}, \mathrm{Ni}$, and $\mathrm{Cr}$ were determined by atomic absorption spectroscopy. In the other part of the membrane filter sample, fluorides were determined after microdiffusion using a colorimetric method with a zirconium-SPANDS complex.
Glass fibre filter

In one part of the glass filter total soluble $\mathrm{Cr}$ was determined by atomic absorption spectroscopy after water extraction. Soluble Cr III was separated from soluble Cr VI in a column filled with s-diphenylcarbazide resin, which retains $\mathrm{Cr}$ VI. Soluble $\mathrm{Cr}$ III was determined in the eluate. After alkaline extraction of the sample, insoluble $\mathrm{Cr}$ VI was determined in the insoluble residue by a colorimetric method with s-

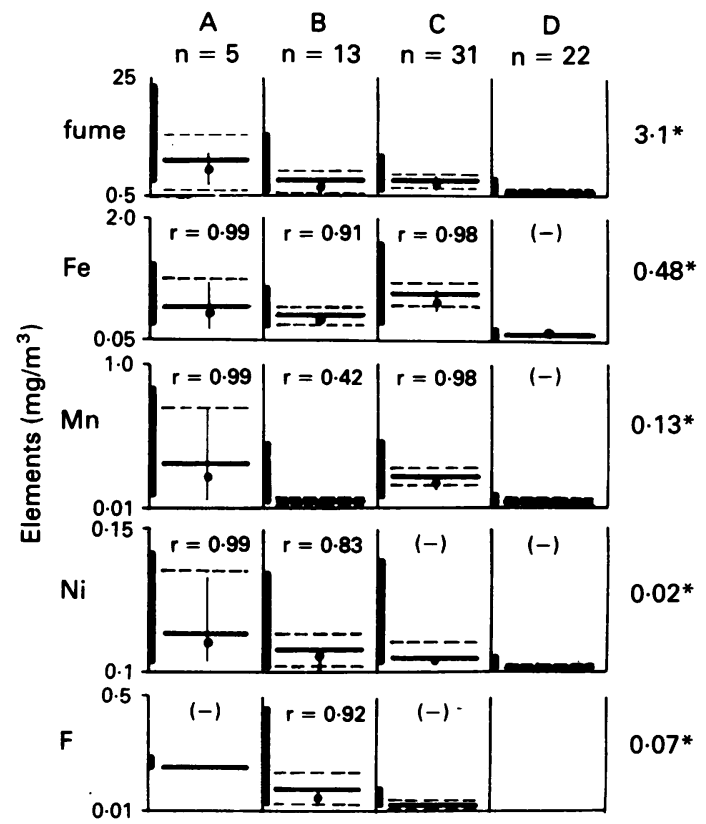

Figure $1 T W A(8 \mathrm{~h})$ concentrations of elements in $M M A /$ $S S$ welding fumes $\left(\mathrm{mg} / \mathrm{m}^{3}\right)$. TW $A=$ time weighted average; $A, B, C, D=$ plants; $=$ range of concentrations;

$\underline{1}=$ arithmetic mean (with confidence intervals); - = geometric mean (with confidence intervals);

$\star=$ mean values of concentrations in all tested plants;

$r=$ correlation coefficient; $\boldsymbol{n}=$ number of measurements;

$(-)=$ no correlation $(p>0.05)$. 


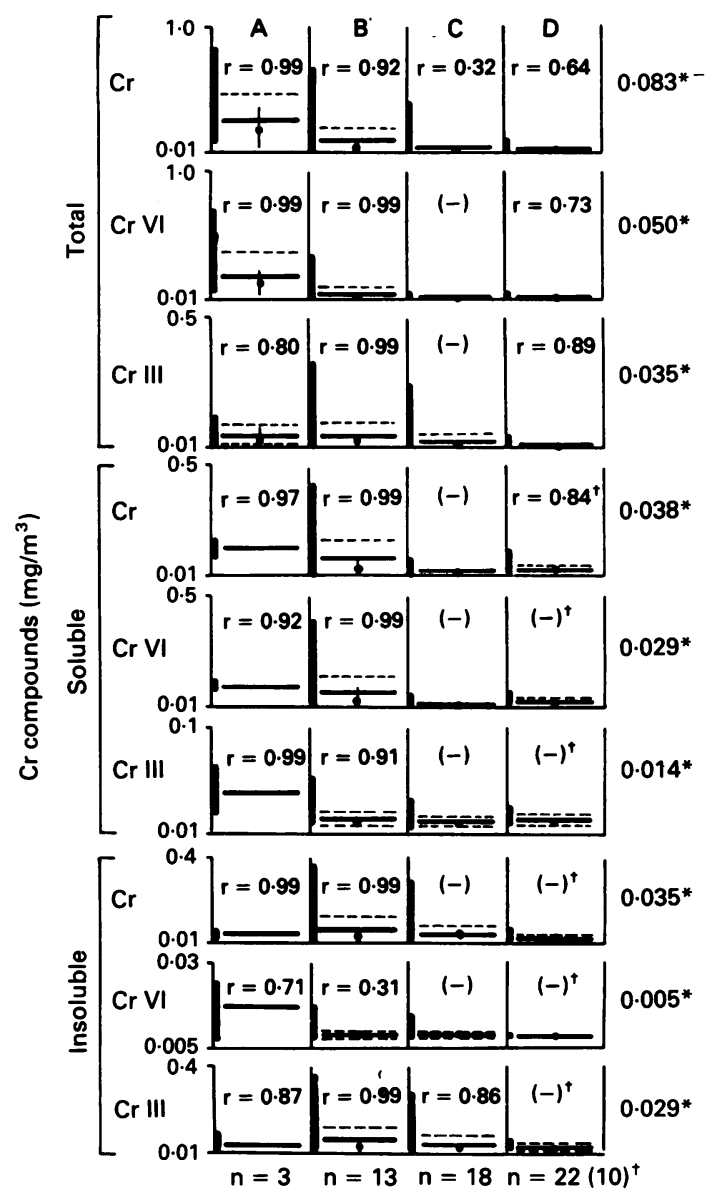

Figure $2 T W A(8 h)$ concentrations of particular $\mathrm{Cr}$ compounds in MMA $/ S S$ welding fumes $\left(\mathrm{mg} / \mathrm{m}^{3}\right)$ (explanations as in fig 1).

diphenylcarbazine. The second part of the glass filter was used to assess the content of total $\mathrm{Cr}$ VI by the same method. All other $\mathrm{Cr}$ values were calculated by difference.

\section{Results}

Figures 1 and 2 present the time weighted average concentrations (TWA-8h) of welding fumes and their major elements $(\mathrm{Fe}, \mathrm{Mn}, \mathrm{Ni}, \mathrm{F}, \mathrm{Cr}$ ) as well as of particular $\mathrm{Cr}$ forms (soluble and insoluble $\mathrm{Cr}$ III and $\mathrm{Cr}$ VI) in the air $\left(\mathrm{mg} / \mathrm{m}^{3}\right)$ of the particular industrial plants $(A, B, C, D)$. They also show mean concentration values from all plants. Welding fume concentrations in the welders' breathing zone ranged from $0 \cdot 2$ to $23.4 \mathrm{mg} / \mathrm{m}^{3}$. The maximum concentration was found in plant $\mathrm{A}$ (mean $9.0 \mathrm{mg} / \mathrm{m}^{3}$; range $2 \cdot 8-23.4$ $\mathrm{mg} / \mathrm{m}^{3}$ ). In plant $\mathrm{C}$, considerably higher concentrations of fumes were found in the welders' breathing zone (mean $3.5 \mathrm{mg} / \mathrm{m}^{3}$; range $1.0-9.1 \mathrm{mg} / \mathrm{m}^{3}$ ) than in that of the welders' assistants (mean $0.8 \mathrm{mg} / \mathrm{m}^{3}$; range $0.2-1.9 \mathrm{mg} / \mathrm{m}^{3}$ ) who only occasionally stayed at the welding posts. Mean fume concentrations in plants $B$ and $\mathrm{D}$ amounted to $3.2 \mathrm{mg} / \mathrm{m}^{3}$ and $1.3 \mathrm{mg} / \mathrm{m}^{3}$ respectively.

Similar values of respirable dust fraction concentrations were obtained in the samples collected in the breathing zone of welders simultaneously on a membrane filter and a glass fibre filter $(r=0.75-0.98)$.

Mean weighted total $\mathrm{Cr}$ concentration in the breathing zone of welders ranged from 0.005 to 0.991 $\mathrm{mg} / \mathrm{m}^{3}$ (fig 2). The highest total $\mathrm{Cr}$ concentration was found in plants $A$ and $B$ in which the work was performed in a half closed area without local exhausts and in a forced body position.

Figure 3 presents the content of particular elements of fumes. The data indicate that the chemical content of fumes in the breathing zone of welders varied greatly. Total $\mathrm{Cr}$ in the fumes occurring in the breathing zone of all welders ranged from $0 \cdot 1 \%$ to $7 \cdot 4 \%$. Mean values of total $\mathrm{Cr}(\%)$ in plants $\mathrm{A}, \mathrm{B}, \mathrm{C}$, and $\mathrm{D}$ were $3.4 \%, 2.5 \%, 1.4 \%$, and $2.6 \%$ respectively.

The relations between concentrations of particular constituents-namely, $\mathrm{Fe}, \mathrm{Mn}, \mathrm{Ni}$, and $\mathrm{Cr}$-and concentration of fumes are presented in the form of correlation coefficients and regressions of the type $y=a+b x$ in particular plants (fig 1) and graphically in the form of simplified lines of the type $y=k x \pm k$ for all plants (fig 4). A low correlation coefficient and lack of linear dependence were obtained for total $\mathrm{Cr}$ in plant $\mathrm{C}$ (welders and their assistants together; fig 2). Figure 4 presents graphically the relation between concentrations obtained for all plants (disregarding welders' assistants from plant $\mathrm{C}$ ). Total $\mathrm{Cr}$ concentration with regard to fumes was characterised by a high correlation coefficient $(r=0 \cdot 89)$.

The results obtained from regression lines $(n=59$, $p=0.05$ ) have facilitated calculation of the mean content of particular elements in fumes (table 2).

Similar relations were determined for concentrations of particular $\mathrm{Cr}$ forms with regard to fume concentration in all plants tested. Figure 5 presents these graphically. Table 3 shows the mean content (\%) of particular $\mathrm{Cr}$ forms in the fumes. This was determined from regression lines $y=k x \pm k$. Participation of particular $\mathrm{Cr}$ forms in relation to total $\mathrm{Cr}$ was determined in the same way (fig 6 , table 4). The relations presented indicate that participation of particular $\mathrm{Cr}$ forms compared with total $\mathrm{Cr}$ content in all samples determined (samples exceeding the sensitivity of the method) was similar (table 4).

Due to considerable variability in the content of fumes in the MMA/SS welders' breathing zone, the evaluation of exposure was based on TWA ( $8 h)$ 

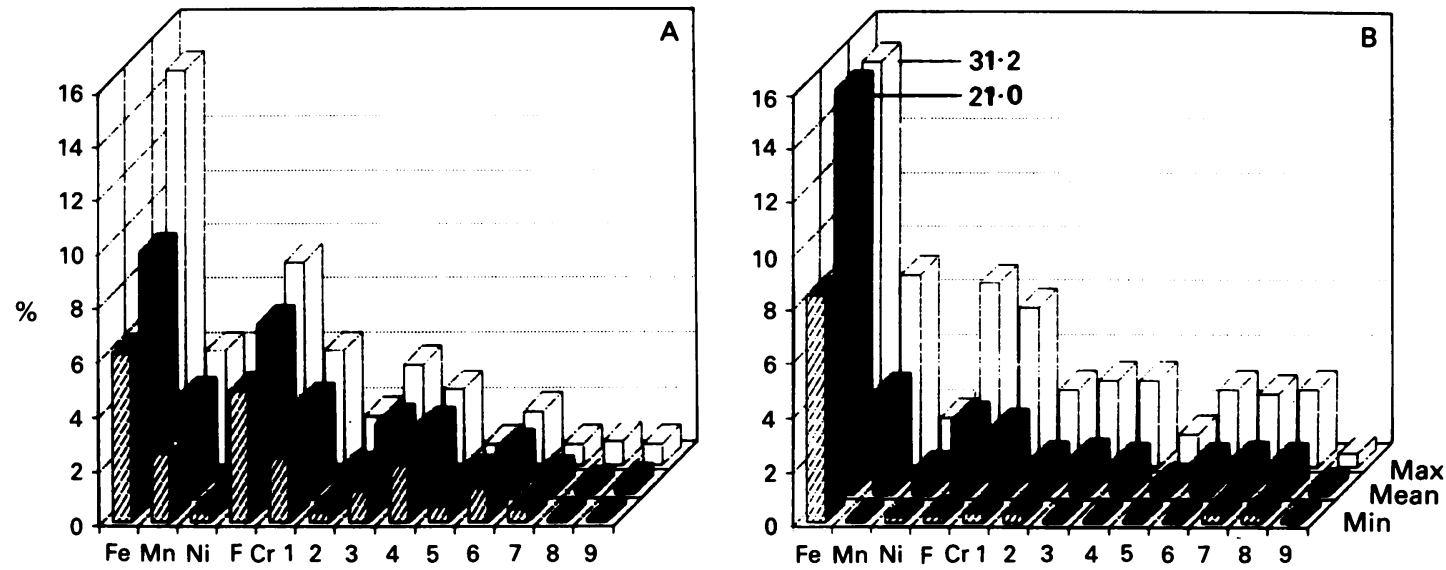

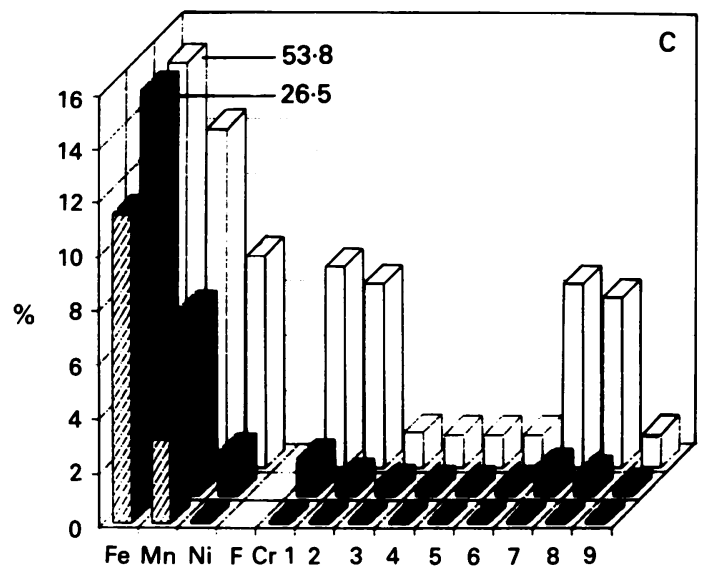

Elements of fume

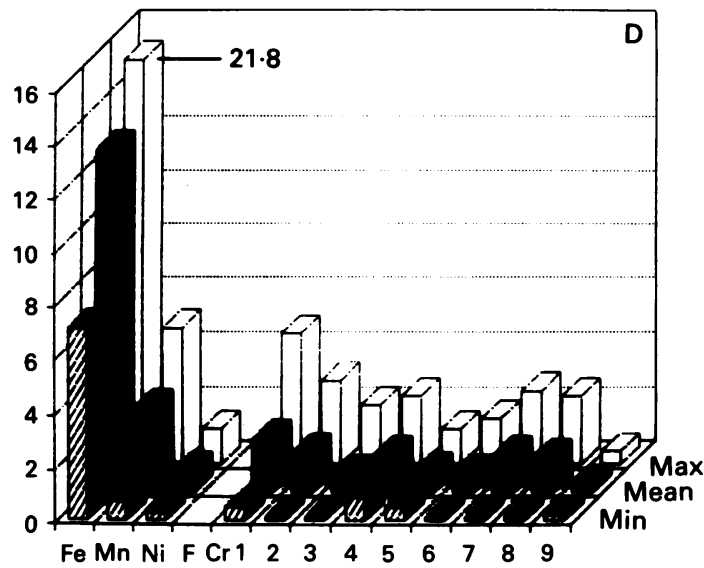

Elements of fume

Figure 3 Percentage content of elements and particular $C r$ compounds in tested plants $(A, B, C, D)$. Cr $1=$ total Cr; $2=$ soluble $\mathrm{Cr} ; 3=$ soluble $\mathrm{Cr}$ III; $4=$ soluble $\mathrm{Cr}$ VI; $5=$ total $\mathrm{Cr}$ VI; $6=$ insoluble Cr; $7=$ insoluble Cr III; $8=$ insoluble Cr VI; $9=$ total $\mathrm{Cr}$ III.

concentrations of fumes for particular elements $(\mathrm{Fe}$, $\mathrm{Mn}, \mathrm{Ni}, \mathrm{F}, \mathrm{Cr}$ VI, Cr III) adopting the principle of their cumulative toxic effect. The evaluation of combined occupational exposure (figs 7-9) allowed us to ascertain that maximum allowable concentrations (MAC) values were exceeded in $42.5 \%$ of MMA/SS welders $(n=72)$. Individual welders' combined exposure to the elements in fumes was 24 times the admissible value for $\mathrm{Cr}$ VI, 17 times for $\mathrm{Ni}$ and three times for $\mathrm{Mn}$ in plant A (fig 7). The hygienic standards for various $\mathrm{Cr}$ forms, mandatory in some other countries, were exceeded for total $\mathrm{Cr}$ VI and soluble $\mathrm{Cr}$ VI in $23-25 \%$ of results and for soluble $\mathrm{Cr}$ VI in 5\% of results, whereas no form of $\mathrm{Cr}$ III exceeded hygienic standards (table 5).

\section{Discussion}

The concentration of MMA/SS welding fumes may vary in particular workplaces from a few to several hundred $\mathrm{mg} / \mathrm{m}^{3} .{ }^{28}$ Stern, ${ }^{20}{ }^{21}$ generalised the data for Swedish and Danish workplaces and found that for MMA/SS processes the medium TWA $(8 \mathrm{~h})$ total dust concentration in the breathing zone varied from 1.5 to $10 \mathrm{mg} / \mathrm{m}^{3}$. An indicator of the range of exposures to total particles was provided by Ulfvarson. ${ }^{16}$

Our studies, performed in detail for the first time in Polish industry, indicated that the TWA $(8 \mathrm{~h})$ of respirable fraction of MMA/SS fumes in the welders breathing zone ranged from 0.2 to $23.4 \mathrm{mg} / \mathrm{m}^{3}$ (mean $3 \cdot 1 \mathrm{mg} / \mathrm{m}^{3}$ ) (fig 1 ). 


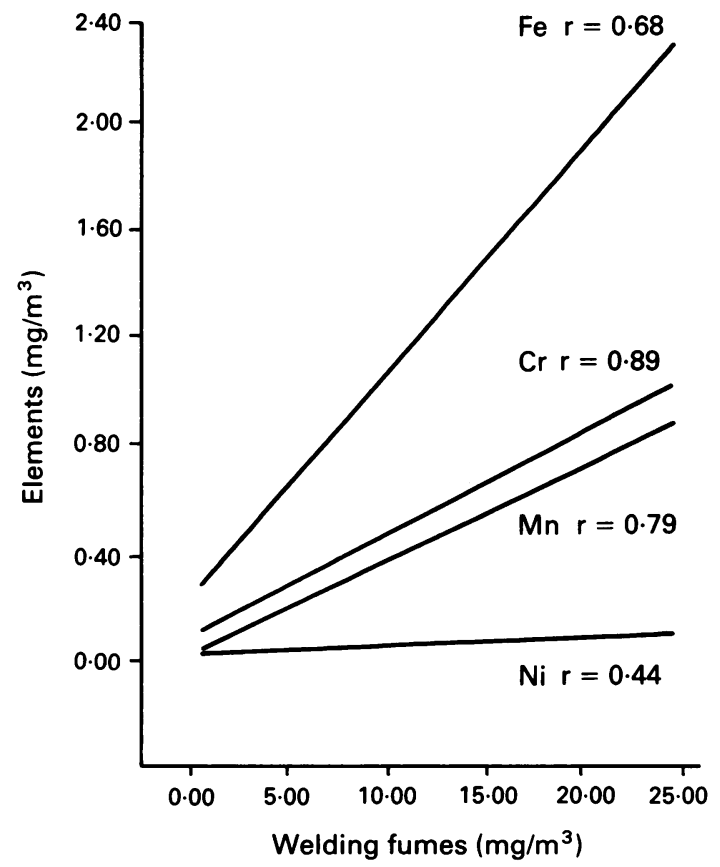

Figure 4 Relation between TWA $(8 h)$ concentrations of elements and $M M A / S S$ welding fumes (plants $A, B, C, D$ ). Number of measurements performed; $=60 . y=$ correlation line $y=k x \pm k$ for: $F e 0 \cdot 112 x \pm 0 \cdot 21$; Mn 0.039x $\pm 0.006 ; \mathrm{Ni} \mathrm{0.005x} \pm 0.002$; Cr $0.036 x \pm 0.005$.

The variations in concentration of particles depend on welding parameters and environmental factors. Working procedures and general and personal prevention systems have an influence on concentrations in fumes.

Also, the presence of some other processes applied in the vicinity affects the chemical composition of the background: under certain conditions, the background may significantly affect the fumes collected in the breathing zone, although usually the background concentration of fumes measured with stationary samplers constitutes about one tenth of that found in the breathing zone. ${ }^{16} 17$

Relations exist between concentrations of elements in fumes and distance from the welding area. The results of our studies indicate that MMA/SS fumes and their elements are usually more concentrated in

Table 2 Mean content of the elements in $M A A / S S$ welding fumes (plants $A, B, C, D$ )

\begin{tabular}{lllll}
\hline Elements (\%) \\
\hline $\mathrm{Fe}$ & $\mathrm{Mn}$ & $\mathrm{Cr}$ & $\mathrm{Ni}$ & $\mathrm{F}$ \\
\hline $11.2(2.1)$ & $3.9(0.6)$ & $3.6(0.5)$ & $0.5(0.2)$ & $3.3(0.6)$ \\
\hline
\end{tabular}

Confidence intervals in parentheses.

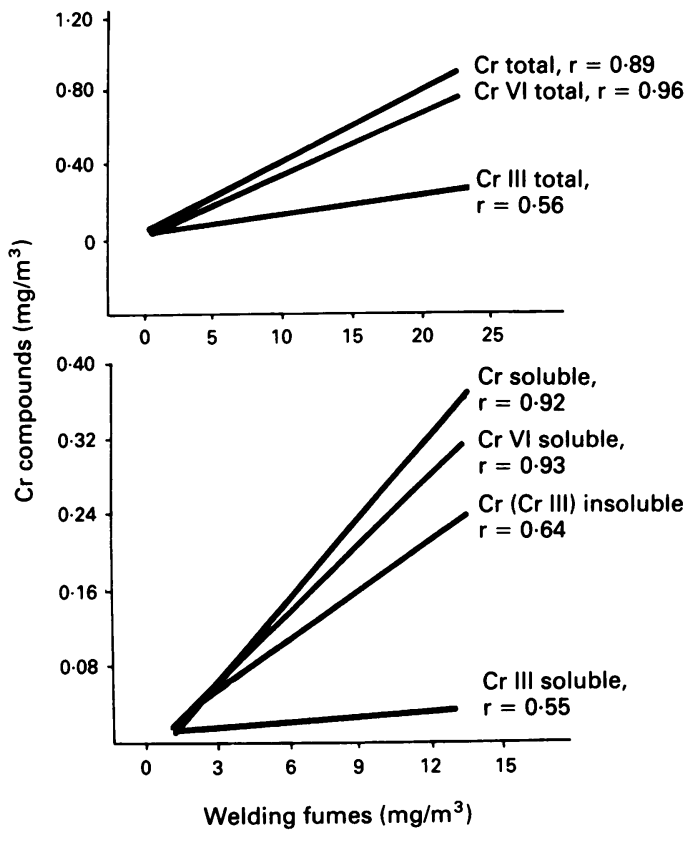

Figure 5 Relation between TWA $(8 h)$ concentrations of particular $C r$ compounds and $M M A / S S$ welding fumes (plants $A, B, C, D) \cdot y=$ correlation line $y=k x \pm k$ for: total Cr 0.036x +0.005; total Cr VI 0.025x \pm 0.003 ; total Cr III $0.011 x \pm 0.003$; soluble Cr 0.023x \pm 0.004 ; soluble $\mathrm{Cr} V I$ $0.023 x \pm 0.004$; soluble Cr III 0.004x \pm 0.001 ; insoluble $\mathrm{Cr}$ III $0.016 x \pm 0.006$.

the breathing zone than in the workplaces. ${ }^{15}$ The individual samples may contain higher percentages of $\mathrm{Cr}$ and $\mathrm{Mn}$ compared with the stationary samples but a lower $\mathrm{Fe}$ percentage. ${ }^{1517}$

The data published by the International Agency for Research on Cancer ${ }^{2}$ show that evaluation of occupational exposure to fumes under some determined conditions can be estimated by combining information on the elemental abundance of the aerosol as determined from a chemical analysis of welding fumes produced in the laboratory under controlled conditions,${ }^{28}$ and the total aerosol concentration expected on the basis of measurements in the workplace. The disadvantage of this technique, however, is that the actual composition of specific welding fumes cannot be determined.

Although the average percentage of elements in MMA/SS welding fumes found in our study (table 3) is similar to the percentage reported by some other authors (Cr 2-9.2; Ni 0.2-3.3; Fe 3.3-15.9; Mn 1.4 $14 \%),{ }^{218-21}$ mean statistical values of particular elements in the welders' breathing zone do not form a real picture of exposure.

The data presented (fig 3 ) indicate that different conditions at the workplace may result in variations in the chemical composition of the fumes. Therefore, 
Table 3 Mean content of particular Cr compounds in MMA/SS welding fumes (plants $A, B, C, D$ )

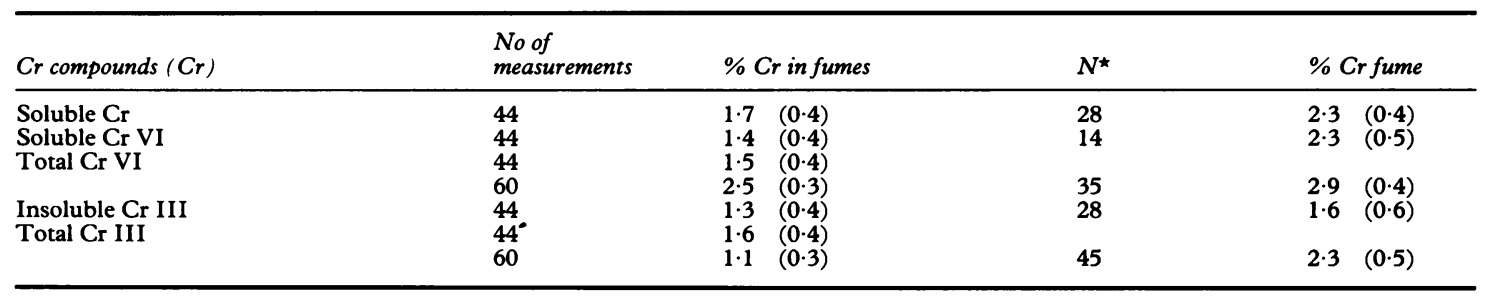

Confidence intervals in parentheses. ${ }^{\star}$ Number of measurements above detection limit.

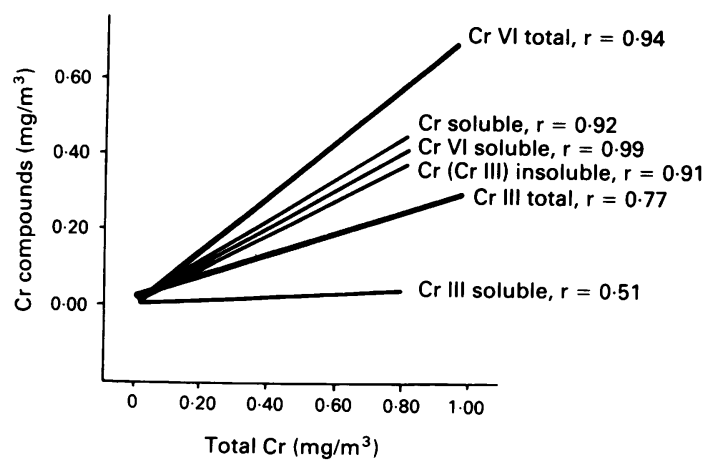

Figure 6 Relation between $T W A(8 h)$ concentrations of particular $\mathrm{Cr}$ compounds and total $\mathrm{Cr}$ in $M M A / S S$ welding fumes (plants $A, B, C, D$ ). $y$-correlation line $y=k x \pm k$ for: total Cr VI 0.685x \pm 0.076 ; soluble Cr 0.526x \pm 0.073 ; soluble Cr VI 0.507x+0.032; insoluble Cr III

$0.479 x \pm 0.066$; total Cr III 0.318x \pm 0.067 ; soluble Cr III $0.082 x \pm 0.037$.

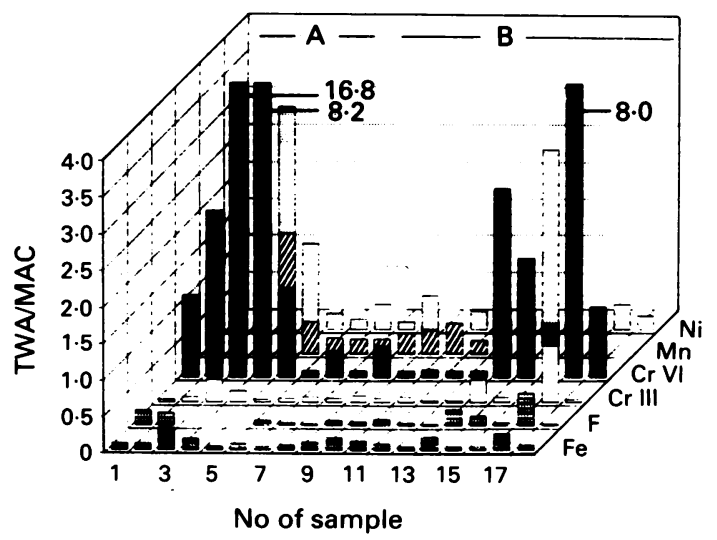

Figure 7 Occupational exposure to elements of $M M A / S S$ welding fumes in plants $A, B$.TW $A=$ time weighted average threshold limit values (Cr III $0.5 \mathrm{mg} / \mathrm{m}^{3}$; Cr VI 0.05 $\left.\mathrm{mg} / \mathrm{m}^{3}\right)^{25} ; M A C=$ maximum allowable concentration $(\mathrm{Fe} 5$ $\mathrm{mg} / \mathrm{m}^{3} ; \mathrm{Mn} 0.3 \mathrm{mg} / \mathrm{m}^{3}, \mathrm{Cr}$ VI $\left.0.05 \mathrm{mg} / \mathrm{m}^{3}\right)^{28}$ ( Ni O.05 $\left.m g / m^{3}\right) .29$

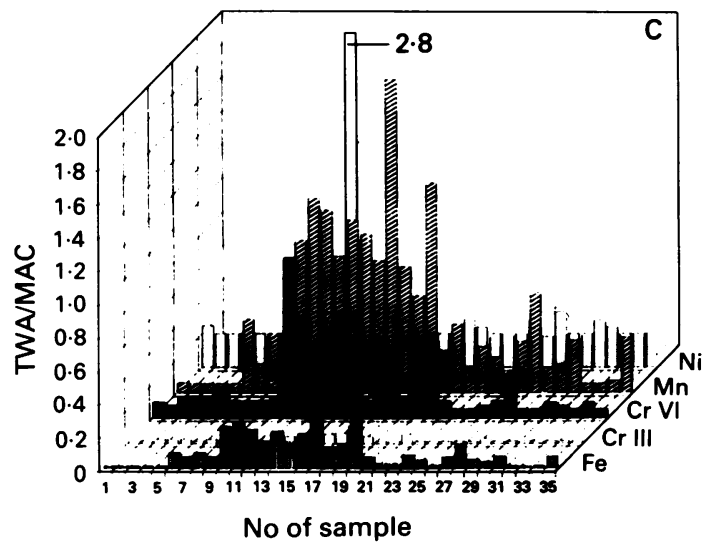

Figure 8 Occupational exposure to elements of $M M A / S S$ welding fumes in plant $C$ (explanation as in fig 7).

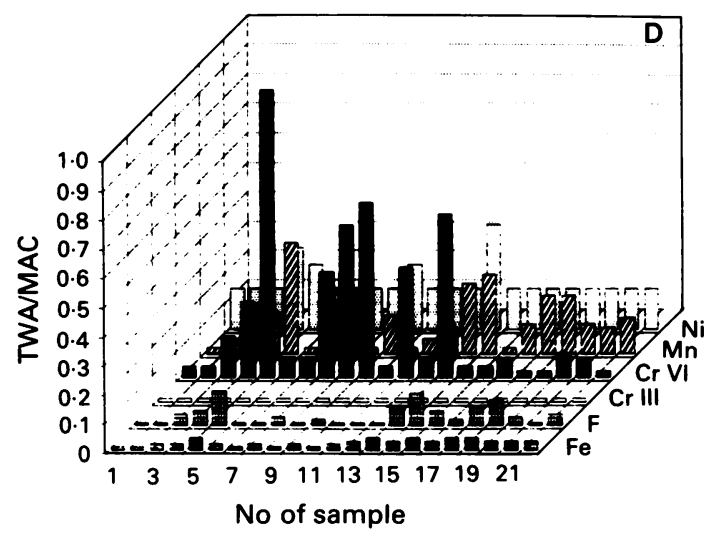

Figure 9 Occupational exposure to elements of $M M A / S S$ welding fumes in plant $D$ (explanation as in fig 7). 
Table 4 Mean content of particular Cr compounds compared to total (plants $A, B, C, D$ )

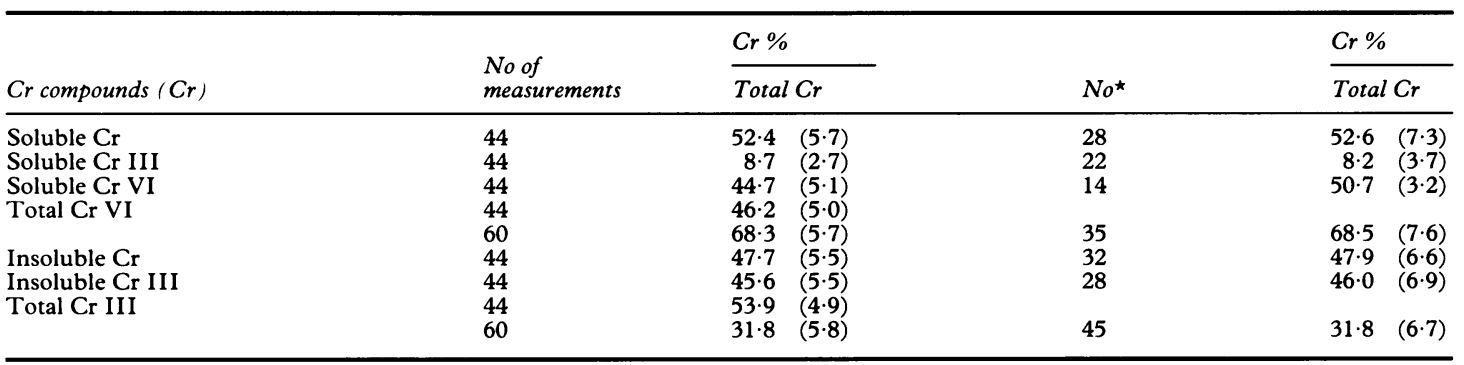

Confidence intervals in parentheses. ${ }^{\star}$ Number of measurements above detection limit.

Table 5 Occupational exposure of $M M A / S S$ welders to particular Cr compounds

\begin{tabular}{|c|c|c|c|c|c|c|}
\hline \multirow[b]{3}{*}{ Plant } & \multicolumn{6}{|c|}{$N o \geqslant T L V \mid N o(\max T W A T L V)$} \\
\hline & \multicolumn{2}{|l|}{ Soluble } & \multirow{2}{*}{$\frac{\text { Total }}{\text { CrVI }}$} & \multicolumn{2}{|c|}{ Insoluble } & \multirow{2}{*}{$\frac{\text { Total }}{\operatorname{Cr} I I I}$} \\
\hline & Cr III & $C t V I$ & & Cr III & $C r V I$ & \\
\hline $\begin{array}{l}\mathrm{A} \\
\mathrm{B} \\
\mathrm{C} \\
\mathrm{D} \\
\mathrm{A}+\mathrm{B}+\mathrm{C}+\mathrm{D}\end{array}$ & $\begin{array}{l}- \\
- \\
-\end{array}$ & $\begin{array}{rr}3 / 3 & (3 \cdot 7) \\
4 / 13 & (15 \cdot 4) \\
1 / 18 & (1 \cdot 3) \\
3 / 10 & (2 \cdot 0) \\
11 / 44 & (15 \cdot 4)\end{array}$ & $\begin{array}{rr}8 / 8 & (16.8) \\
4 / 13 & (8.0) \\
1 / 18 & (1.0) \\
1 / 22 & (1.0) \\
14 / 60 & (16.8)\end{array}$ & $\begin{array}{l}- \\
- \\
-\end{array}$ & $\begin{array}{ll}\overline{1 / 13} & (1 \cdot 3) \\
1 / 18 & (1 \cdot 3) \\
\frac{2}{2 / 41} & (1 \cdot 3)\end{array}$ & $\begin{array}{l}- \\
- \\
-\end{array}$ \\
\hline $\mathrm{TLV}\left(\mathrm{mg} / \mathrm{m}^{3}\right)$ & $0 \cdot 5^{25}$ & $0.025^{26}$ & $0 \cdot 05^{25}$ & $0.5^{25}$ & $0 \cdot 01^{2627}$ & $0 \cdot 5^{25}$ \\
\hline
\end{tabular}

$\mathrm{TLV}=$ threshold limit value; $\mathrm{TWA}=$ time weighted average.

individual measurements in the breathing zone of welders during a shift are absolutely necessary to determine the risk of exposure.

In recent studies ${ }^{29}$ considerable attention has been paid to the oxidation state of $\mathrm{Cr}$ in welding fumes, and it has always been taken into account in our previous $^{15}$ and current studies. In most studies on MMA/SS fumes, the concentration of $\mathrm{Cr}$ VI (mostly water soluble) ranged from 0.025 to 1.550 $\mathrm{mg} / \mathrm{m}^{3} .291022$

In our studies, the occurrence of high concentrations of $\mathrm{Cr}$ VI in MMA/SS fumes (range 0.005-0.8 $\mathrm{mg} / \mathrm{m}^{3}$; fig 2) was confirmed as well as a high relative content of total $\mathrm{Cr}$ VI with high concentrations of soluble Cr VI (tables 2-4, figs 3-6). A considerable excess over the hygienic standards for individual exposure ${ }^{25-29}$ was also noted (table 5, figs 7-9).

The high Cr VI content (36-100\% of total $\mathrm{Cr}$ ) in MMA/SS fumes in attributed to the presence of alkaline metals in the flux coating. In the study of Kobayashi and Tsutsumi, ${ }^{23}$ potassium was replaced by sodium in a modified electrode, resulting in a significant reduction in the relative $\mathrm{Cr}$ VI content (soluble Cr VI $-5 \cdot 6 \%$, insoluble Cr VI $-11 \cdot 2 \%$ ). Actually, the insoluble Cr VI content in MMA/SS welding fumes ranged from 0.03 to $0.92 \%{ }^{2182124}$ and $\mathrm{CrO}_{3}$ content from $0 \cdot 4-1 \cdot 8 \%$. The mean value of $0 \cdot 2-$ $0.3 \%$ is negligible from the point of view of exposure. $^{2}$

In our study, however, we found that insoluble $\mathrm{Cr}$ VI content in welding fumes varied from $0 \cdot 1$ to $1 \cdot 2 \%$, in dust with an average $0.3 \%$.

The data on the insoluble Cr VI content in MMA/ SS welding fumes, especially in industry, have been a subject of discussion. Taking into account the fact that $\mathrm{Cr}$ VI has been considered to be a human carcinogen, ${ }^{2}$ no safe level for Cr VI can be recommended. It seems that its occurrence in fumes even at a concentration less than $0.005-0.842 \mathrm{mg} / \mathrm{m}^{3}$ may create a serious health risk (fig 2 , table 5 ).

\section{CONCLUSIONS}

Evaluation of occupational exposure has indicated that MMA/SS welders may exceed the admissible concentrations of soluble and insoluble $\mathrm{Cr}$ VI, $\mathrm{Mn}$, and $\mathrm{Ni}$.

Due to various changeable parameters in the working environment, the content of fumes in the welders' breathing zone is not constant and hence it is not possible to use one universal exposure indicator 
allowing for a standard mean content of fumes. The evaluation of exposure should be based on the results of measurements of particular elements of fumes in the welders' breathing zone.

1 Lees PSJ. Chromium and disease: Review of epidemiologic studies with particular reference to etiologic information provided by measures of exposure. Environ Health Perspect 1991;92:93-104.

2 International Agency for Research on Cancer. Monographs on the evaluation of carcinogenic risk to humans. Chromium, nickel and welding. Vol 49, Lyon: IARC, 1990:49-256, 447-527.

3 Aitio A, Jarvisalo J, Kulunen M, et al. Chromium. In: Clarkson TW, Friberg L, Nordberg GF, Sager PR, eds. Biological monitoring of toxic metals. New York: Plenum Press, 1988: monitoring

4 De Floro S, Bagnasco M, Serra D, et al. Genotoxicity of chromium compounds. A review. Mutat Res 1990;238:99172.

5 Langard S. One hundred years of chromium and cancer: A Review of epidemiological evidence and selected case reports. Am J Ind Med 1990;17:189-215.

6 Sjogren B. A retrospective cohort study of mortality among stainless steel welders. Scand J Work Environ Health 1980; 6:197-200.

7 Becker N, Claude J, Frentzel-Beyme R. Cancer risk of arc welders exposed to fumes containing chromium and nickel. Scand J Work Environ Health 1985;11:75-82.

8 Stern RM, Berlin A, Fletcher AC, Jarvisalo J, eds. Health hazards and biological effects of welding fumes and gases. Amsterdam: Excerpta Medica, 1986.

9 Pedersen B, Thomsen E, Stern RM. Some problems in sampling, analysis and evaluation of welding fumes containing Cr (VI). Ann Occup Hyg 1987;31:325-38.

10 Van der Wall JF. Exposure of welders to fumes containing $\mathrm{Cr}$, $\mathrm{Ni}, \mathrm{Cu}$ and gases in Dutch industries. Ann Occup Hyg 1985; 29:377-89.

11 Matczak W, Chmielnicka J. Methods for determining soluble and insoluble $\mathrm{Cr}$ III and $\mathrm{Cr}$ VI compounds in welding fumes. Polish Journal of Occupational Medicine 1989;2:376-88.

12 Matczak W, Chmielnicka J. Evaluation of welders occupational exposure to insoluble Cr VI compounds. Fourth congress of Polish association of toxicology. Jastrzebia Gora: 24-26 September 1990.

13 Matczak W, Chmielnicka J. Evaluation of occupational exposure to $\mathrm{Cr}$ III and Cr VI compounds in welding fumes. Seventeenth international congress on occupational health in the chemical industry - Medichem '89. Cracow: 26-29 September 1989.

14 Matczak W, Chmielnicka J, Trzcinka M. A relation between chromium in air and chromium in urine of welders. Fourth congress of Polish association of toxicology. Jastrzebia Gora: 2426 September 1990.
15 Matczak W, Chmielnicka J. Evaluation of occupational exposure to chromium compounds in MMA/SS welding fumes. The 1991 Eurotox Congress. Maastricht, The Netherlands: September 1991.

16 Ulfvarson U. Survey of air contaminants from welding. Scand $J$ Work Environ Health 1981;7(Suppl 2):1-28.

17 Rahkonen E, Junttila ML, Kalliomaki PL, et al. Evaluation of biological monitoring among stainless steel workers. Int Arch Occup Environ Health 1983;52:243-55.

18 Moreton J, Day SE, Jenkins N. Fume emission rate measurements and fume analysis on four stainless steel welding consumables. In: Stern RM, Berlin A, Fletcher AC, Jarvisalo I, eds. Health hazards and biological effects of welding fumes and gases. Amsterdam: Excerpta Medica, 1986:61-4.

19 Thomsen E, Stern RM. A simple analytical technique for the determination of hexavalent chromium in welding fumes and other complex matrices. Scand J Work Environ Health 1979; 5:386-403.

20 Stern RM. Chromium compounds, production and occupational exposure. In: Langard S, ed. Biological and environmental aspects of chromium. Amsterdam: Elsevier, 1982.

21 Stern RM. Occupational exposure in the welding industry: health risk assessment. In: Health effects of combined exposures to chemicals in work and community environments. Proceedings of a Course by the European Cooperation on environmental health aspects of the control of chemicals. Lodz, Poland, 18-22 October 1982. Copenhagen: World Health Organisation, 1983:226-61.

22 Coenen W, Grothe J, Kuhnen G, et al. Nickel and chromate in welding fume. Staub Reinhaltung der Luft 1985;45:546-50.

23 Kobayashi $M$, Tsutsumi $S$. Investigation on crystalline materials in welding fumes of covered electrodes. In: Stern RM, Berlin A, Fletcher AC, Jarvisalo J, eds. Health hazards and biological effects of welding fumes and gases. Amsterdam: Excerpta Medica, 1986:77-80.

24 Stern RM. A chemical, physical and biological assay of welding fume. In: Brown RC, Cormley IP, Chamberlin M, Davis R, eds. The in vitro effects of mineral dusts. London: Academic Press, 1980:203-9.

25 American Conference of Governmental Industrial Hygienists. $T L V s$, threshold limit values and biological exposure indices for 1988-1989. Cincinnati: OH 1988:15-6, 24, 38.

26 National Institute for Occupational Safety and Health. NIOSH recommendations for occupational safety and health standards. Cincinnati: 1988. (Morbid Mortal Rep 37 (Suppl 17):9.)

27 Group of Experts for Chemical Agents. The MAC values documentation. Chromates (as $\mathrm{Cr}$ ). Intersectoral Commission for updating register of $M A C$ and $M A J$ values, Poland, 1987.

28 Ordinance of the Minister of Labour, Earnings and Social Affairs on the Maximum Permissible Concentrations and Intensities of Harmful Agents in the Work Environment. Journal of Law of the Polish People's Republic 1989 No 69 position 417.

29 Valeurs limited pour les concentrations des substances dangereuses dans l'air des lieux de travail (en Union sovietique). Cahiers de notes documentaires No 129; 49 trimestre 1987.

Accepted 8 June 1992 